\title{
Analysis of Contaminant and Nutritional Content of Red Galangal (Alpinia purpurata K. Schaum) Simplicia
}

\author{
Mirwa Adiprahara Anggarani ${ }^{1}$, Nita Kusumawati ${ }^{2}$ \\ Department of Chemistry \\ Universitas Negeri Surabaya \\ Surabaya, Indonesia \\ ${ }^{1}$ mirwaanggarani@unesa.ac.id, \\ 2nitakusumawati@unesa.ac.id
}

\author{
Roy Januardi Irawan \\ Department of Sports Science \\ Universitas Negeri Surabaya \\ Surabaya, Indonesia \\ royirawan@unesa.ac.id
}

\author{
Rusijono \\ Department of Educational Technology \\ Universitas Negeri Surabaya \\ Surabaya, Indonesia \\ rusijono@unesa.ac.id
}

\begin{abstract}
This study has been conducted analysis of contaminant and nutritional content of red galangal (Alpinia purpurata K. Schaum) simplicia. Simplicias as one of post-harvest processed form. Simplicia is a material to produce herbs medicine. So that, simplicia quality must be considered. The quality of simplicias depends on two parameters that are contaminant and nutritional content. Contaminants can reduce product quality, so it must be controlled. As well as contaminant, nutritional content also must control, because it is affected quality of simplicia product. Nutritional content that must be controlled are essential oil, monoterpene on essential oil, oleoresin, saponin, tannin, and flavonoid. Simplicia is produced by, washing, slicing and drying methods. Whereas contaminants contained in simplicia are lead, copper, arsenic, total plate number, E. Coly, mold, and aflatoxin. From this study, produced red galangal simplicia with nutritional content, $\mathbf{1 . 9 8 \%}$ essential oil, $37.92 \%$ monoterpene on essential oil, $1.34 \%$ oleoresin, $0.74 \%$ saponin, $0.21 \%$ tannin, and $0.12 \%$ flavonoid. While, contamination on simplicia product includes $1.13 \mathrm{mg} / \mathrm{Kg}$ lead, $1.21 \mathrm{mg} / \mathrm{Kg}$ copper, $0.05 \mathrm{mg} / \mathrm{Kg}$ arsenic, $1.93 \times 104$ colony/g total plate number, $<10 \mathrm{apna} / \mathrm{g}$ E. Coli, $<10$ colony/g mold, and 2.76 $\mathrm{mg} / \mathrm{Kg}$ aflatoxin. From the result of this study, that are contaminants and nutritional content, the simplicia product has conformed to the standard of drug quality according to SNI.
\end{abstract}

Keywords - red galangal, simplicia, contaminant, nutritional content

\section{INTRODUCTION}

Red galangal (Alpinia purpurata K. Schaum) is a native Indonesian plant and traditionally utilized for a range of illness and can be developed as traditional medicine. Most people use the rhizome of this plant as they believe it has medicinal effect. Rhizomes have been used as stomachic, aphrodisiac, tonic, diuretic, expectorant, carminative; useful in headache, rheumatic pains, sore throat, sour eructation, stuttering, pain in chest, diabetes, burning of the liver, tubercular glands and diseases of the kidney [1].

The cultivation of the galangal as a spice is now carried out in many tropical areas of Asia. The herb is mostly propagated by rhizomes, grows best in shaded areas away from direct sunlight, it also requires well drained soils to grow in and is usually propagated by dividing and replanting the rhizomes during the spring. The four to six years old plants are harvested for their rhizomes at the end of the growing season. Harvested rhizomes are carefully washed and cut into segments and then dried for storage and processing into herbal medicine [2],[3].

The rhizome also contains flavonoids, some of which have been identified as kaempferol, kaempferide, galangin and alpinin. Kaempferide, galangin and alpinin have also been isolated from galangal roots. The pale-yellow oil with a pleasant odour is obtained from green rhizomes on distillation. The oil contains $48 \%$ methyl cinnamate, $20-30 \%$ cineole, $\alpha$ pinene, $\beta$-pinene and camphor [4].

Material handling after harvesting time need to be considered due to the quality of the processed product. The quality and safety of biopharma product, one of which in the form of simplicia, determined by the quality of raw material, post-harvest handling and processing techniques. The postharvest handling techniques consist of stages of sorting, washing, and drying [5], sorting/grading, packaging, labeling, and storage, either before sold in fresh form or after further processing. However, until today there is no researcher who reported in detail about the standard operating procedures (SOP) for the manufacture of processed products after harvesting.

Quality of rhizome simplicia depends on contaminant and nutritional content. Whereas contaminants contained in simplicia are lead, copper, arsenic, total plate number, E. Coli, 
mold, and aflatoxin. As well as contaminant, nutritional content also must control, because it is affected quality of simplicia product. Nutritional content that must be controlled are essential oil, monoterpene on essential oil, oleoresin, saponin, tannin, and flavonoid.

Based on its usefulness and standard control of simplicia product, a research is needed on analysis of contaminant and nutritional content of red galangal (Alpinia purpurata $K$. Schaum) simplicia by standard methods of simplicia production.

\section{MATERIAL AND METHODS}

\section{A. Material}

The main material used in this research is red galangal (Alpinia purpurata K. Schaum). The optimization of postharvest handling of red galangal was conducted using a number of apparatuses as in previous publication [6], which include washer (homemade) used to optimize washing time with NESCO Lab MS-H280 Pro-magnetic stirrer as a motor producing whirlpool which is used in order to remove contaminants, Bosch MUZ4DS3 slicer machine with slicing capacity of $60 \mathrm{~g} / \mathrm{min}$ and the slicing thickness of $0.30 \mathrm{~cm}$; JLabTech LDO-030E (Daihan Labtech Ltd. Co.) drying machine with a range temperature of $50{ }^{\circ} \mathrm{C}-250{ }^{\circ} \mathrm{C}$ and a drying time up to 60 minutes, which is used to optimize rhizome drying.

\section{B. Methods}

Post-harvest handling of red galangal rhizome is done through three main stages covering washing, slicing, and drying. In the initial stages, fresh red galangal rhizomes are washed for 1 to 3 minutes. After being washed, galangal rhizomes is dried with sunlight for 24 hours. After drying, red galangal is sliced with a thickness of $0.5 \mathrm{~mm}$ to $1 \mathrm{~mm}$. After the process of slicing, it is re-dried.

The standard methods to produce red galangal simplicias is the washing time for 1-3 minutes, slice thickness for $0.5 \mathrm{~mm}$ to $1 \mathrm{~mm}$, and drying time and drying methods for 24 hour using sunlight, and final drying methods using oven for $80^{\circ} \mathrm{C}$ is stopped as soon as constant mass is obtained.

\section{Functional compound testing of temulawak simplicia product}

The testing procedure of functional compound content of red galangal simplicias products include essential oil content using Stahl distillation methods. The testing procedure of oleoresin, tannin, and flavonoid, using UV Visible Spectrophotometer Pharmaspec UV-1700. The testing procedure of saponin using thin layer chromatography.

\section{Contaminant Testing of Red Galangal Simplicia}

After the red galangal simplicia product was obtained, the contamination test of red galangal simplicia product was carried out to get the best qualification. Tests of contamination, both biological and chemical, carried out include analysis of levels of metal contamination including: (1) Lead $(\mathrm{Pb})$; (2)
Copper; (3) Arsenic; (4) Microbial contamination (total plate number, E. coli, mold, aflatoxin).

\section{RESUlT AND DISCUSSION}

Data in Table 1 shows the Quality Requirements of Red Galangal Simplicia [7]

TABLE I. QUALITY STANDARD OF TEMULAWAK SIMPLICIA ISSUED BY MATERIA MED INDONESIA

\begin{tabular}{|c|l|c|c|}
\hline Num & \multicolumn{1}{|c|}{ Criteria } & Unit & Requirements \\
\hline $\mathbf{1 . 0}$ & Metal contaminant & & \\
\hline 1.1 & Lead $(\mathrm{Pb})$ & $\mathrm{mg} / \mathrm{kg}$ & Max. 10.0 \\
\hline 1.2 & Copper $(\mathrm{Cu})$ & $\mathrm{mg} / \mathrm{kg}$ & Max. 30.0 \\
\hline 1.3 & Arsenic $(\mathrm{As})$ & $\mathrm{mg} / \mathrm{kg}$ & Max. 0.1 \\
\hline $\mathbf{2 . 0}$ & Microbial contaminant & & \\
\hline 2.1 & Total plate number & colony $/ \mathrm{g}$ & Max. $10^{6}$ \\
\hline 2.2 & E. coli & $\mathrm{apna} / \mathrm{g}$ & Max. $10^{3}$ \\
\hline 2.3 & Mold & colony/g & Max. $10^{4}$ \\
\hline 3.0 & Aflatoxin & $\mathrm{mg} / \mathrm{kg}$ & Max. 20.0 \\
\hline
\end{tabular}

The presence of metal lead, copper and arsenic in food products that exceed the threshold can endanger human health. Lead metal is a metal that is very popular and widely known by ordinary people. This is due to the large number of $\mathrm{Pb}$ used in non-food industries and most causing poisoning in living things. Metal $\mathrm{Pb}$ can enter the body through breathing, food and drinks.

The metals $\mathrm{Hg}, \mathrm{Pb}$, and $\mathrm{Cd}, \mathrm{Cu}$ (copper) is an essential microelement for all plants and animals, including humans. $\mathrm{Cu}$ metal is needed by various enzyme systems in the human body. Therefore, $\mathrm{Cu}$ must always be in food. What needs to be considered is to keep the $\mathrm{Cu}$ levels in the body no less and excessive. Body needs per day of $\mathrm{Cu}$ is $0.05 \mathrm{mg} / \mathrm{kg}$ body weight. At this level $\mathrm{Cu}$ accumulation does not occur in the human body. Large amounts of $\mathrm{Cu}$ can cause acute symptoms.

Most of the arsenic in nature is a form of basic compounds in the form of inorganic substances. Inorganic arsenic can be water-soluble or gaseous and exposed to humans. According to the National Institute for Occuptional Safety and Health (1975), inorganic arsenic is responsible for various chronic health disorders, especially cancer. Arsenic can also damage the kidneys and is a very strong poison.

Not only metal contamination, microbial contamination in food products can also pose a fatal risk to human health. Therefore, at this stage of the study, the contamination of galangal simplicia products was analyzed, not only metal contamination, but also microbial contamination. The total plate number (TPN) is a quantitative method used to determine the number of microbes present in a test sample. TPN test is a method for calculating the number of mesophyll aerobic bacteria contamination contained in a sample by pour plate method on solid media and incubated for 24-48 hours at a temperature of $34-35{ }^{\circ} \mathrm{C}$ with the position reversed. The methods used include pouring, dropping and spreading. The principle of this test is the growth of mesophyll aerobic bacterial colonies after the samples are inoculated on the agar plate media by pouring, and incubated at the appropriate 
temperature. TPN that exceeds the limit can be dangerous especially for nursing mothers and their babies. These bacteria can produce toxins that cause various diseases including diarrhea, vomiting and fever. Specific to spice products, as indicated by SNI 01-3709-1995, the maximum value of the total allowable plate number is 106 colonies / g.

E. coli is one type of bacteria that establishes coliform and lives normally in human and animal kotan. Therefore, these bacteria is also called faecal coliform. Specific to simplicia products, as required by SNI 01-3709-1995, the maximum quantity of E. coli allowed is 103 apna / g. E. Coli quantity in simplicia rhizome products which exceeds the predetermined threshold can cause food poisoning and serious infections.

In addition to total plate numbers and E. coli, the level of mold contamination in simplicia products also needs to be considered. Fungi are members of the fungus regnum which usually grows on the surface of food that has been stale or not treated for too long. Its presence is too large (exceeding the threshold) in food products, can cause food poisoning. Specifically, as required by SNI 01-3709-1995, the maximum quantity of mold permitted on the simplicia product is equal to 104 colonies / g.

Aflatoxin is the main parameter in addition to metal and microbial contamination that can show the quality of a product. Aflatoxin is a mycotoxin produced by A.flavus or $A$. parasiticus and is hepatocarcinogen. Excessive presence of aflatoxin in a food product can trigger liver damage in humans. Considering the level of danger that can be triggered by the presence of aflatoxin, the government sets the threshold for the presence of aflatoxin in the simplicia product, which is $20 \mathrm{mg} /$ $\mathrm{kg}$.

Data in Table 1 shows the analysis of contamination of red galangal simplicia products.

TABLE II. DATA FROM THE ANALYSIS OF CONTAMINATION OF RED GALANGAL SIMPLICIA PRODUCTS

\begin{tabular}{|c|l|c|}
\hline Num & \multicolumn{1}{|c|}{ Criteria } & Amount \\
\hline 1 & Metal contaminant & $1.13 \mathrm{mg} / \mathrm{kg}$ \\
\hline 1.1 & Lead $(\mathrm{Pb})$ & $1.21 \mathrm{mg} / \mathrm{kg}$ \\
\hline 1.2 & Copper $(\mathrm{Cu})$ & $0.05 \mathrm{mg} / \mathrm{kg}$ \\
\hline 1.3 & Arsenic $(\mathrm{As})$ & \\
\hline 2 & Microbial contaminant & $1.93 \times 10^{4}$ colonies $/ \mathrm{g}$ \\
\hline 2.1 & Total plate number & $<10 \mathrm{apna} / \mathrm{g}$ \\
\hline 2.2 & E. coli & $<10 \mathrm{colonies} / \mathrm{g}$ \\
\hline 2.3 & Mold & $2.76 \mathrm{mg} / \mathrm{kg}$ \\
\hline 3 & Aflatoxin & \\
\hline
\end{tabular}

In this study, also conducted nutritional analysis of red galangal simplicia products with the best qualifications resulting from the standardization stage.

The red galangal rhizome (Alpinia purpurata $K$. Schum) contains anti-bacterial substances, namely in the form of essential oil, monoterpene in essential oil, oleoresin, saponins, tannins, and flavonoids. To maintain the high usefulness of active compounds of red galangal material, in this study also analyzed the content of active compounds of red galangal production of galangal. The optimization results of the red galangal simplicia production process that have been carried out by involving blanching and drying processes with a reversal quantity of simplicia material during drying twice a hour have resulted in the highest quality red galangal simplicia products. The complete data on the nutritional content of red galangal simplicia are shown in table 3 .

TABLE III. NUTRITIONAL CONTENT OF FRESH AND SIMPLICIA FROM RED GALANGAL

\begin{tabular}{|c|l|c|c|}
\hline \multirow{2}{*}{ Num } & \multirow{2}{*}{ Nutritional Content } & \multicolumn{2}{|c|}{ Amount } \\
\cline { 3 - 4 } & & $\begin{array}{c}\text { Fresh red } \\
\text { galangal }\end{array}$ & $\begin{array}{c}\text { Red galangal } \\
\text { simplicia }\end{array}$ \\
\hline 1 & Essential oil & $1.98 \%$ & $1.39 \%$ \\
\hline 2 & Monoterpene in essential oil & $37.92 \%$ & $37.18 \%$ \\
\hline 3 & Oleoresin & $1.34 \%$ & $1.31 \%$ \\
\hline 4 & Saponin & $0.74 \%$ & $0.72 \%$ \\
\hline 5 & Tannin & $0.21 \%$ & $0.21 \%$ \\
\hline 6 & Flavonoids & $1.12 \%$ & $0.12 \%$ \\
\hline
\end{tabular}

The results of the analysis of nutritional levels of red galangal simplicia compared to fresh red galangal showed a decrease in the levels of active compounds of red galangal simplicia products as a result of a series of production stages of red galangal simplicia, especially blanching and drying stages.

Drying is the oldest preservation technique of agricultural products and it is essential process used all over the world for the preservation of farm produce. It helps in reducing the water activity of the produced simplicia to a level below which deterioration does not occur for a definite duration (Prasad et al., 2006 and Borah et al., 2015). Lower water content will have a direct impact on the easily covered with mold and bacteria, eliminates the activity of enzymes that can decipher the active compound content, facilitate further processing, so it can be more compact, durable and stored (Kusumawati et al., 2017). However, the decline is not significant, so the red galangal simplicia product is still of good quality

\section{CONCLUSION}

From this research, produced red galangal simplicia with nutrional content, $1.98 \%$ essential oil, $37.92 \%$ monoterpene on essential oil, $1.34 \%$ oleoresin, $0.74 \%$ saponin, $0.21 \%$ tannin, and $0.12 \%$ flavonoid. While, contamnination on simplicia product includes $1.13 \mathrm{mg} / \mathrm{Kg}$ lead, $1.21 \mathrm{mg} / \mathrm{Kg}$ copper, 0.05 $\mathrm{mg} / \mathrm{Kg}$ arsenic, $1.93 \times 104$ colony/g total plate number, $<10$ apna/g E. Coli, $<10$ colony/g mold, and $2.76 \mathrm{mg} / \mathrm{Kg}$ aflatoxin.

\section{ACKNOWLEDGMENT}

The authors would like to thank to Direktorat Penelitian dan Pengabdian Masyarakat Kementrian Riset dan Teknologi Pendidikan Tinggi Republik Indonesia which has provided financial support through National Priority Research Program Masterplan of Acceleration and Expansion of Indonesia Economic Development.

\section{REFERENCES}

[1] K.R. Kirtikar and B.D. Basu, Indian Medicinal Plants, vol. IV, International Book Distribution: Dehra Dun, 1996, pp. 2445-2446. 
[2] M. Coen, R. Engel and A. Nahrstedt, "Phenylpropanoids-chavicol $\beta$-dglucopyranoside," Phytochemistry, vol. 40(5), pp. 149, 1995.

[3] W.J. Kress, L.M. Prince and K.J. Williams, "The phylogeny and a new classification of the Gingers (Zingiberaceae): evidence from molecular data, Amer. J. Bot., vol. 89(11), pp. 1682-1696, October 2002.

[4] D.J. Charles, J.E. Simon and N.K. Singh, "Bio Active Principles/Chemical Constituents- The essential oil of Alpinia galanga Willd," J. Essen. Oil Res., vol. 4(1), pp. 81-82, 1992.

[5] R. Paramawati, Mardison, S. Triwahyudi, and R.Y. Gultom, "Design and testing of horizontal type of mechanical rhizome chopper," Indonesian J. of Agriculture, vol. 3(1), pp. 39-44, 2010.
[6] N. Kusumawati, M.A. Anggarani, Rusijono, P. Setiarso, S. Muslim, "Product standardization of ginger (Zingiber officinale Rosc.) and red ginger (Zingiber officinale var. Rubrum) simplicia through washing time, slice thickness and raw materials drying process optimization," International J. on Advanced Science Engineering Information Technology, vol. 7, pp. 15-21, 2017.

[7] M. Raharjo, O. Rostiana,. Budidaya Tanaman Temulawak. Sirkuler No. 11. Balai Penelitian Tanaman Obat dan Aromatik. Badan Penelitian dan Pengembangan Pertanian, Bogor, 2005.

[8] J. Prasad, V.K. Vijay, G.N. Tiwari, V.P.S. Sorayan, "Study on performance evaluation of hybrid drier for turmeric (Curcuma Longa L.) drying at village scale," J. Food. Eng, vol. 75, pp. 497-502, 2006. 